\title{
Campuran kitosan dengan resin akrilik sebagai bahan gigi tiruan penghambat Candida albicans
}

\author{
Titik Ismiyati*, Widowati Siswomihardjo**, Marsetyawan Heparis Nur Ekandaru Soesatyo***, R. Rochmadi**** \\ *Departemen Prostodonsia, Fakultas Kedokteran Gigi, Universitas Gadjah Mada, Yogyakarta, Indonesia \\ ${ }^{* *}$ Departemen IImu Biomaterial Kedokteran Gigi, Fakultas Kedokteran Gigi, Universitas Gadjah Mada, Yogyakarta, Indonesia \\ ${ }^{* * *}$ Departemen Histologi, Fakultas Kedokteran, Universitas Gadjah Mada, Yogyakarta, Indonesia \\ ****Jurusan Teknik Kimia, Fakultas Teknik, Universitas Gadjah Mada, Yogyakarta, Indonesia \\ *JI Denta No 1, Sekip Utara, Yogyakarta, Indonesia; e-mail : ismiyati.titik@yahoo.co.id
}

Submisi: 4 April 2017; Penerimaan: 21 November 2017; Publikasi online: 29 Desember 2017

\begin{abstract}
ABSTRAK
Penghambatan Candida albicans pada gigi tiruan resin akrilik dapat memainkan peran penting dalam mencegah perkembangan denture stomatitis. Kitosan adalah senyawa polimer alam yang berasal dari limbah udang yang dapat berfungsi sebagai antijamur. Resin akrilik tidak dapat bercampur dengan kitosan. Untuk mendapatkan campuran yang homogen, campuran tersebut ditambah coupling agent asam akrilat dan aseton. Penelitian ini bertujuan untuk mengkaji campuran resin akrilik dan kitosan dan asam akrilat pelarut aseton sebagai bahan gigi tiruan penghambat Candida albicans. Spesimen penelitian berbentuk cakram berdiameter $10 \mathrm{~mm}$ dan tebal $2 \mathrm{~mm}$ dibuat dari resin akrilik kuring panas (QC 20) dicampur dengan kitosan dari cangkang udang yang ditambahkan asam akrilat dalam pelarut aseton. Spesimen dibagi menjadi 4 kelompok. Kelompok 1 terdiri dari resin akrilik tanpa kitosan sebagai kontrol, sedangkan kelompok 2, 3, dan 4 terdiri dari campuran resin akrilik dengan kitosan $5 \mathrm{ml}$ pada konsentrasi $0,5 \%, 1 \%$, dan $2 \%$, secara berurutan. Hasil campuran resin akrilik dengan kitosan dianalisis dengan menggunakan Fourier Transform Infrared spectroscopy (FTIR), dan digital mikroskop optik. Efek antijamur diuji dengan menggunakan metode dilusi. Data yang didapat dianalisis statistik dengan Kruskal Wallis. Hasil penelitian menunjukkan bahwa campuran resin akrilik dengan kitosan signifikan menghambat pertumbuhan Candida albicans. Berdasarkan hasil yang diperoleh, dapat disimpulkan bahwa campuran resin akrilik dan kitosan dapat bersifat fungistatik, sehingga dapat dikembangkan sebagai bahan gigi tiruan antijamur.
\end{abstract}

Kata kunci: Candida albicans; gigi tiruan; kitosan; resin akrilik

\begin{abstract}
The mixture of acrylic resin and chitosan as denture material to inhibit Candida albicans. The inhibition of Candida albicans in denture resin has an important role to prevent the development of denture stomatitis. Chitosan is a natural polymer compound derived from shrimp waste which can function as an antifungal Acrylik resin cannot be mixed with chitosan. To obtain a homogeneous mixture, the mixture was added a coupling agen acrylic acid and acetone. The research objective was to study the mixture of acrylic resin and chitosan with solvent acrylic acid and acetone as a denture that can inhibit the growth of Candida albicans. Methods: The samples used discs in $10 \mathrm{~mm}$ diameter and $2 \mathrm{~mm}$ thickness, made from heat cured acrylic resin mixed with chitosan dissolved in acrylat acid and acetone. They were divided into 4 groups. Group 1 was acrylic resin without chitosan as a control, group 2 , 3 and 4 were the mixture of acrylic resin and $5 \mathrm{ml}$ chitosan in $0.5 \%, 1 \%$, and $2 \%$ concentration respectively. The fourier transform irfrared spectroscopy (FTIR) and the digital optical microscope were used to synthesize and analyze. The Kruskal Wallis was used to analyze the data. The results showed that the mixture of acrylic resin with chitosan significantly inhibited the growth of Candida albicans. Conclusion: a mixture of acrylic resins and chitosan can be fungistatic, so it can be developed as an antifungal denture material.
\end{abstract}

Keywords: Candida albicans; denture; chitosan; acrylic resin

\section{PENDAHULUAN}

Berdasarkan riset terhadap masyarakat Indonesia yang dilakukan oleh Kementerian Kesehatan RI tahun 2013, persentase penduduk yang mengalami kehilangan gigi dan menerima perawatan gigi tiruan meningkat seiring dengan bertambahnya usia. ${ }^{1}$
Gigi tiruan merupakan protesa pengganti gigi asli yang hilang dan jaringan pendukungnya. Macam gigi tiruan terdiri dari gigi tiruan cekat, gigi tiruan lepasan sebagian dan gigi tiruan lengkap. Sejak tahun 1946, 98\% gigi tiruan menggunakan bahan dasar resin akrilik. ${ }^{2}$ Kelemahannya, permukaan 
resin akrilik dapat memicu pertumbuhan bakteri dan Candida albicans yang mempunyai peranan penting sebagai penyebab terjadinya denture stomatitis. ${ }^{3}$ Perlekatan Candida albicans pada plat resin akrilik dapat dicegah dengan bahan kumur ekstrak etanolik kulit jambu mete. ${ }^{4}$

Saat ini telah ditemukan kitosan yang mempunyai fungsi sebagai antibakteri. ${ }^{5}$ Kitosan telah banyak dimanfaatkan dalam berbagai bidang misalnya bidang pangan, mikrobiologi, pertanian, kesehatan, dan farmasi. Kitosan adalah keturunan kitin yang diperoleh melalui proses deasetilasi dan dapat ditemukan pada exoskeleton dari Crustasea, salah satunya dari udang. Kitosan adalah polisakarida dengan rumus umum $\left(\mathrm{C}_{6} \mathrm{H}_{11} \mathrm{NO}_{4}\right)_{n}$ atau $\beta$-(1-4)-2-amino-2deoksi-D-glucopyranosa. ${ }^{6}$ Secara biologi, kitosan aman karena memiliki sifat biokompatibel dan biodegradasi yaitu dapat terurai di alam dan telah diaplikasi dalam bidang kedokteran gigi, misal penyembuhan luka, regenerasi jaringan, dan bahan hemostatik. ${ }^{7}$ Selain berfungsi sebagai antibakteri, kitosan juga dapat digunakan sebagai antijamur. Aktivitas antijamur kitosan tergantung pada berat molekul dan konsentrasi. ${ }^{8}$ Penambahan kitosan yang mempunyai berat molekul rendah dan tinggi pada komposit resin dapat direkomendasikan sebagai antibakteri streptococcus mutans. ${ }^{9}$ Pencampuran nano kitosan berat molekul tinggi dengan bahan termoplastik nilon dapat menghambat pertumbuhan Candida albicans. ${ }^{10}$ Beberapa penelitian menunjukkan konsentrasi kitosan $0,5 \%$ dan $1 \%$ dapat mengambat pertumbuhan bakteri dan jamur pada keju. ${ }^{11}$

Kitosan dapat digunakan sebagai antimikroba karena mempunyai gugus $\mathrm{NH}_{2}^{+}$yang mampu berinteraksi dengan permukaan sel bakteri yang bermuatan negatif, kemudian teradsorbsi membentuk lapisan yang menghambat transportasi sel. Akibatnya, sel bakteri kekurangan substansi untuk berkembang sehingga kemudian mengalami kematian. ${ }^{12}$ Kematian sel bakteri juga dapat terjadi akibat interaksi antara muatan positif pada kitosan dan negatif pada permukaan sel bakteri yang mengubah permeabilitas permukaan sel bakteri sehingga penyusun sel bakteri seperti protein, asam amino dan glukosa akan hilang. ${ }^{13}$ Kitosan mempunyai muatan dwi kutub yaitu muatan negatif pada gugus karboksilat dan positif pada gugus amina sehingga diperkirakan dapat bereaksi dengan bahan bermuatan seperti protein, polisakarida, asam lemah, dan makromolekul. ${ }^{6}$ Perkiraan adanya ikatan antara molekul radikal bebas atau elektron tidak berpasangan pada metakrilat ( $\mathrm{COO}^{-}$) dengan molekul $\mathrm{NH}_{2}^{+}$yang merupakan zat reaktif pada kitosan, ${ }^{14}$ mendorong penelitian terhadap pencampuran kitosan dengan resin akrilik yang terdiri dari polimer polimetakrilat dan monomer metil metakrilat. Hasil pencampuran diharapkan dapat menjadikan resin akrilik sebagai gigi tiruan yang memiliki kemampuan anti-bakteri. Namun demikian dalam ilmu kimia, pencampuran dua atau lebih bahan dapat menghasilkan distribusi bahan secara homogen atau heterogen. Pencampuran homogen dapat terjadi apabila zat yang dicampur mempunyai parameter kelarutan yang sama atau mendekati. Kitosan dan resin akrilik mempunyai parameter kelarutan yang tidak sama. Kelarutan resin akrilik $38,49 \mathrm{Joule}^{1 / 2} \mathrm{~cm}^{3 / 2}$, sedangkan kitosan $41 \mathrm{Jolue}^{1 / 2} \mathrm{~cm}^{3 / 2} \cdot{ }^{15}$ Dengan demikian, resin akrilik dan kitosan menghasilkan campuran yang tidak homogen.

Homogenitas campuran mempengaruhi sifat mekanik suatu bahan. Oleh karena itu apabila campuran bahan belum homogen, maka diperlukan suatu bahan penghubung atau coupling agent, agar sifat mekanik tetap terjaga. Termasuk dalam coupling agent adalah maleat anhidrat dan asam lemah asam akrilat serta aseton sebagai bahan pelarut. Reaksi antara resin akrilik dengan kitosan dan asam akrilat dalam pelarut aseton melibatkan gugus $\mathrm{NH}_{2}^{+}$yang bersifat basa pada kitosan dengan karboksilat $(\mathrm{C}=\mathrm{O})$ pada asam akrilat yang bersifat asam. Asam akrilat bereaksi dengan resin akrilik pada waktu terjadi polimerisasi, sehingga kitosan yang telah bereaksi dengan asam akrilat tersebut dapat tercampur dengan baik dengan resin akrilik. Aseton adalah pelarut yang tidak ikut bereaksi dan menguap atau hilang pada saat zat yang dilarutkan bereaksi. Manfaat pada penelitian ini untuk mengkaji campuran kitosan dengan resin akrilik sebagai bahan gigi tiruan yang dapat menghambat pertumbuhan Candida albicans. Manfaat penelitian adalah untuk dapat dikembangkan bahan yang dipakai untuk pembuatan gigi tiruan yaitu bahan 
resin akrlik dicampur yang dengan kitosan konsenrasi tertentu yang mempunyai kemampuan menghambat pertumbuhan Candida albicans.

\section{METODE PENELITIAN}

Prosedur dalam penelitian ini telah mendapatkan persetujuan dari komisi etik Fakultas Kedokteran Gigi dengan nomor 005837/KKEP/FKG-UGM/ EC/2016. Spesimen dibagi menjadi 4 kelompok. Kelompok 1 terdiri dari resin akrilik tanpa campuran dengan kitosan sebagai kontrol, kelompok 2 resin akrilik dicampur dengan kitosan konsentrasi 0,5\%, kelompok 3 resin akrilik dicampur $1 \%$ dan kelompok 4 resin akrilik dicampur dengan kitosan $2 \%$.

Pembuatan campuran kitosan konsentrasi $0,5 \%, 1 \%$, dan $2 \%$ dengan asam akrilat dan aseton dilakukan menggunakan stirer sampai homogen selama 60 menit pada suhu $40{ }^{\circ} \mathrm{C}$. Diambil $5 \mathrm{ml}$ larutan kitosan pada masing masing konsentrasi kemudian dimasukkan ke dalam polimer dan monomer resin akrilik. Perbandingan polimer : monomer adalah 2,35:1. Adonan diaduk hingga terjadi fase dough, dilanjutkan proses polimerisasi secara pemanasan menggunakan curing unit $70{ }^{\circ} \mathrm{C}$ selama $2 \mathrm{jam}$ kemudian $100{ }^{\circ} \mathrm{C}$ selama 1 jam. Masing-masing kelompok perlakuan terdiri dari 6 spesimen yang kemudian, direndam dalam akuades selama 48 jam, di autoclave selama 18 menit, kemudian direndam saliva buatan selama 1 jam. ${ }^{16}$ Spesimen dimasukkan ke dalam $10 \mathrm{ml}$ biakan Candida albicans selama 24 jam suhu 37 ${ }^{\circ} \mathrm{C}$. Selanjutnya, spesimen diambil, dimasukkan ke dalam conical tube yang berisi $10 \mathrm{ml}$ akuades, dan digetarkan dengan vortex mixer selama 1 menit. Setelah pengenceran $10^{-3}, 10^{-1} \mathrm{ml}$ suspensi diambil kemudian dibiakkan pada media Saboraud Dextrose Agar yang diinkubasi selama 24 jam pada $37{ }^{\circ} \mathrm{C}$. Penghitungan koloni jamur dilakukan menggunakan colony counter.

\section{HASIL PENELITIAN}

Langkah awal yang dilakukan pada penelitian ini adalah melarutkan kitosan dengan asam akrilat dan aseton kemudian dicampur dengan polimer dan monomer resin akrilik. Hasil campuran yang berupa plat dibuat serbuk, kemudian dilakukan analisis keberadaan gugus reaktif kitosan yang dapat tercampur dengan molekul resin akrilik. Analisis dilakukan menggunakan Fourier Transform Infrared Spectroscopy (FTIR).

Gambar 1 menunjukkan puncak serapan tajam pada $1735 \mathrm{~cm}^{-1}$. Hal ini menunjukkan terjadinya regangan pada karbonil (-COO). Keadaan ini menunjukkan adanya asam akrilat. Puncak serapan pada $1627 \mathrm{~cm}^{-1}$, gugus C dan $\mathrm{N}$ mengalami penurunan penyerapan getaran. Kejadian yang menunjukkan adanya kitosan yang telah terikat pada resin akrilik adalah peningkatan peregangan $\mathrm{C}-\mathrm{H}$ pada puncak $1450 \mathrm{~cm}^{-1}$ dan 1141 $\mathrm{cm}^{-1}$. Pita serapan pada bilangan gelombang 3549 $\mathrm{cm}^{-1}$ dan $3410 \mathrm{~cm}^{-1}$ menunjukkan adanya gugus $\mathrm{OH}$ dan N-H. Serapan gelombang lebih besar 3549 $\mathrm{cm}^{-1}$ berkaitan dengan intensitas ikatan hidrogen yang lebih luas dalam spectrum kopolimerisasi dari kitosan, menunjukkan bahwa terdapat lebih banyak ikatan hidogen yang dapat menghasilkan pembentukan molekul.

Struktur resin akrilik tanpa kitosan dan campuran resin akrilik dengan kitosan. Campuran resin akrilik dengan kitosan menunjukkan keberadaan kitosan berwarna keputihan yang tersebar di sebagian besar permukaan. Gambaran resin akrilik menggunakan mikroskop optik perbesaran 200x disajikan pada Gambar 2 dan 3. Gambar 4 dan 5 menunjukkan koloni Candida albicans pada kelompok kontrol lebih banyak dibandingkan kelompok perlakuan. Hasil penghitungan rerata dan standar deviasi angka jamur dapat dilihat pada Tabel 1.

Data yang diperoleh digunakan untuk menghitung angka jamur dalam satuan CFU/ml dengan rumus: Angka Jamur $=$ jumlah koloni $x$ faktor pengencer $(\mathrm{CFU} / \mathrm{ml})$. volume larutan yang dihitung ................................. Persamaan 1)

Angka jamur yang didapat digunakan untuk mengetahui Konsentrasi Hambat Minimal (KHM) dengan rumus: $\mathrm{KHM}=100 \%$ - angka jamur konsentrasi tertentu (CFU/ml) angka jamur larutan kontrol (CFU/ml) Persamaan 2) 


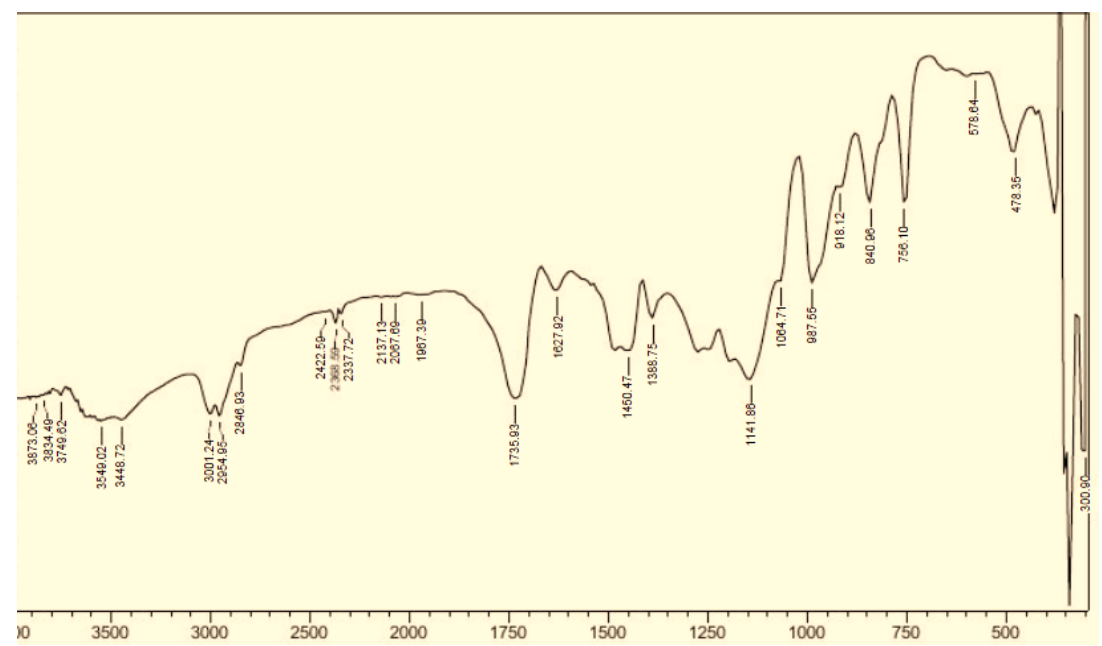

Gambar 1. Spektrum FTIR serbuk campuran resin akrilik dan kitosan dengan asam akrilat aseton

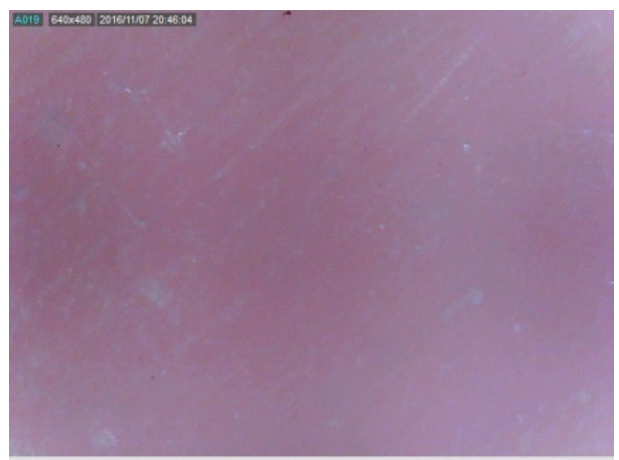

Gambar 2. Campuran resin akrilik tanpa kitosan (pembesaran 200x).

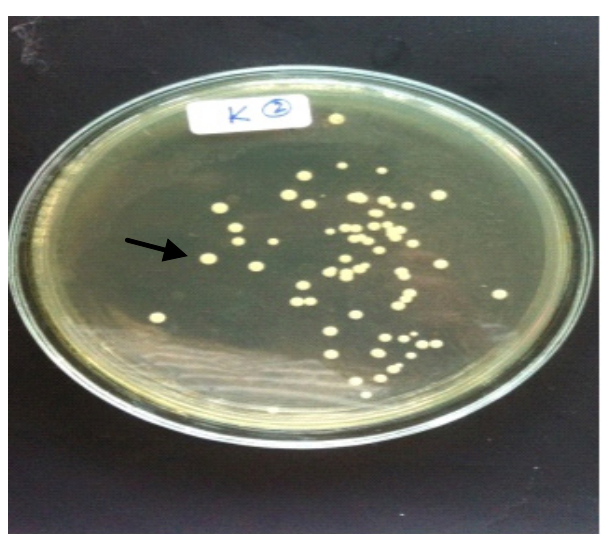

Gambar 4. Koloni Candida albicans pada kelompok kontrol Tanda $(\longrightarrow$ ) menunjukkan Candida albicans

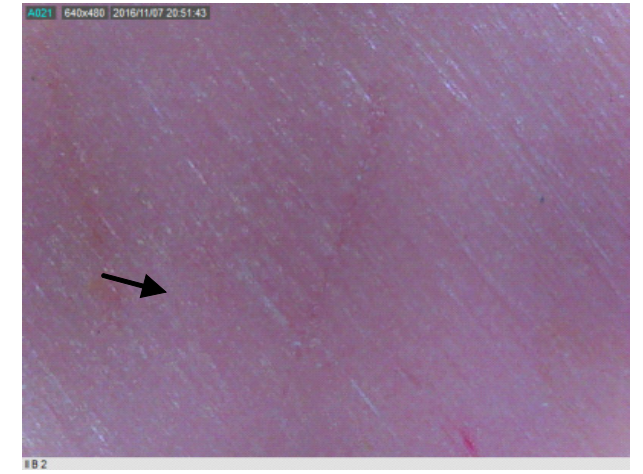

Gambar 3. Campuran resin akrilik dengan kitosan dan asam akrilat pelarut aseton.(Pembesaran 200x). Tanda $(\longrightarrow$ ) menunjukkan kitosan

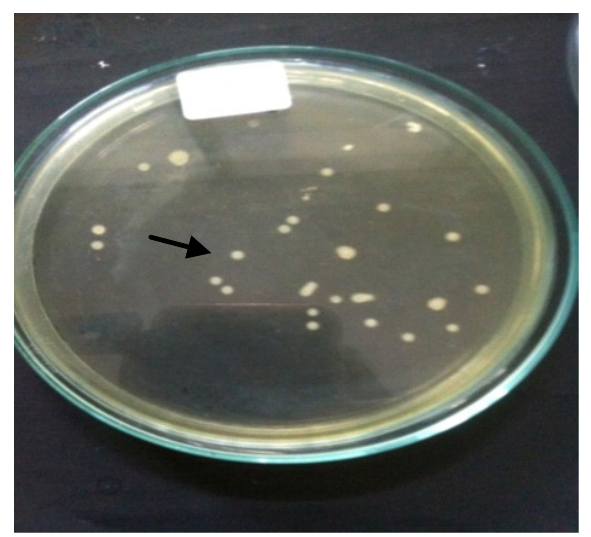

Gambar 5. Koloni Candida albican pada perlakuan. Tanda $(\rightarrow$ ) menunjukkan Candida albicans 
Tabel 1. Rerata dan standar deviasi angka jamur Candida albicans pada kelompok kontrol dan kelompok perlakuan ( $\mathrm{x}$ $\left.10^{7} \mathrm{CFU} / \mathrm{ml}\right)$

\begin{tabular}{cccc}
\hline Konsentrasi kitosan & $\mathrm{N}$ & Rerata & Std. Deviasi \\
\hline Kontrol & 6 & 1.2417 & $\pm 0,38923$ \\
$0,5 \%$ & 6 & 0,3567 & $\pm 0,07090$ \\
$1 \%$ & 6 & 0,2200 & $\pm 0,06782$ \\
$2 \%$ & 6 & 0,0650 & $\pm 0,02074$ \\
Total & 24 & 0,4708 & $\pm 0,50290$ \\
\hline
\end{tabular}

Tabel 2. Hasil uji Tamhane antara kelompok perlakuan terhadap pertumbuhan Candida albicans

\begin{tabular}{ccccc}
\hline Kelompok & Kontrol & $\begin{array}{c}\text { Konsentrasi } \\
\text { kitosan 0,5\% }\end{array}$ & $\begin{array}{c}\text { Konsentrasi } \\
\text { kitosan 1\% }\end{array}$ & $\begin{array}{c}\text { Konsentrasi } \\
\text { kitosan 2\% }\end{array}$ \\
\hline Kontrol & 0,013 & 0,007 & 0,004 \\
$0,5 \%$ & & 0,039 & 0,000 \\
$1 \%$ & & & 0,011 \\
$2 \%$ & & & \\
\hline
\end{tabular}

Berdasarkan data pada Tabel 1, angka jamur tertinggi terdapat pada kelompok kontrol, kemudian menurun pada kelompok perlakuan konsentrasi $0,5 \%, 1 \%$ dan $2 \%$. Angka jamur tertinggi pada kelompok perlakuan, terdapat pada konsentrasi kitosan $0,5 \%(0,3567 \pm 0,07090)$ sedangkan angka terendah pada konsentrasi $2 \%(0,0650 \pm 0,02074)$.

Hasil uji Kruskal Wallis untuk pertumbuhan Candida albicans terhadap konsentrasi kitosan menunjukkan nilai signifikan $p<0,05$. Nilai ini menunjukkan adanya perbedaan angka jamur Candida albicans yang signifikan antara kelompok konsentrasi kitosan. Untuk mengetahui signifikasi penghambatan Candida albicans pada masingmasing konsentrasi kitosan, penghitungan dilanjutkan dengan analisis post hoc pada data yang tidak homogen yaitu dengan Tamhane (Tabel 2).

Hasil perhitungan post hoc dengan Tamhane menunjukkan bahwa terdapat perbedaan angka jamur Candida albicans yang bermakna antara kontrol dengan semuakelompok perlakuan $(p<0,05)$. Angka jamur Candida albicans pada kelompok kontrol lebih besar dibandingkan pada kelompok perlakuan dengan konsentrasi kitosan $0,5 \%, 1 \%$, dan $2 \%$. Angka jamur pada kelompok konsentrasi $0,5 \%$ lebih besar dibanding dengan konsentrasi
1\%. Angka jamur paling kecil didapatkan pada konsentrasi $2 \%$ dibanding perlakuan yang lain. Penghitungan konsentrasi hambat minimal pada kelompok konsentrasi $0,5 \%$ adalah $71,27 \%$, pada konsentrasi $1 \%$ sebesar $82,28 \%$, dan konsentrasi $2 \%$ didapatkan $94,76 \%$.

\section{PEMBAHASAN}

Hasil penelitian menunjukkan bahwa rerata angka jamur tertinggi terdapat pada kelompok kontrol, kemudian menurun pada kelompok perlakuan campuran resin akrilik dengan kitosan $0,5 \%, 1 \%$ dan $2 \%$. Halinimenunjukkankitosandapatmenyebabkan angka jamur Candida albicans menurun. Dengan kata lain, kitosan dapat menghambat pertumbuhan Candida albicans. Kitosan dapat bersifat antijamur karena memiliki muatan positif $\mathrm{NH}_{2}{ }^{+}$yang dapat berinteraksi dengan muatan negatif pada dinding jamur sehingga mengubah permeabilitas dinding sel dan menimbulkan ketidakseimbangan tekanan internal sel. Hal ini mengakibatkan kebocoran elektrolit intraseluler dan menyebabkan sel jamur lisis kemudian mati. ${ }^{14}$

Hasil penelitian ini menunjukkan semakin tinggi konsentrasi kitosan diikuti dengan angka jamur yang semakin rendah. Kitosan konsentrasi rendah mempunyai kandungan senyawa bioaktif $\left(\mathrm{NH}_{2}{ }^{+}\right)$ lebih rendah, sehingga potensi untuk menghambat jamur berkurang sehingga angka jamur menjadi tinggi. Sebaliknya, semakin tinggi konsentrasi maka gugus $\mathrm{NH}_{2}{ }^{+}$semakin tinggi, sehingga lebih dapat menghambat pertumbuhan jamur. Hal ini sesuai dengan penelitian terdahulu yang menyatakan bahwa semakin tinggi konsentrasi suatu zat, maka mikroorganisme sel akan mengalami kematian atau terhambat pertumbuhannya. ${ }^{17}$ Hasil uji Kruskal Wallis menunjukkan nilai $p<0,05$, artinyaterdapatperbedaan yang bermakna antara konsentrasi kitosan terhadap nilai angka jamur. Analisis post hoc menunjukkan pada setiap kelompok terdapat perbedaan yang bermakna. Angka jamur kelompok kontrol yaitu resin akrilik tanpa kitosan didapatkan hasil angka jamur berbeda dan paling tinggi dibandingkan dengan kelompok perlakuan konsentrasi $0,5 \%, 1 \%$ dan $2 \%$. Hal ini karena kelompok kontrol tidak mengandung kitosan sehingga tidak terdapat gugus $\mathrm{NH}_{2}^{+}$yang 
berfungsi sebagai anti jamur, oleh karena itu jumlah angka jamurnya tertinggi dibanding dengan kelompok perlakuan yang mengandung kitosan. Kitosan Konsentrasi 0,5\% menunjukkan angka jamur yang tinggi, kemudian angka jamur tersebut menurun pada konsentrasi yang semakin meningkat. Hal tersebut kemungkinan disebabkan karena pada kitosan konsentrasi yang tinggi mengandung gugus $\mathrm{NH}_{2}$ dalam jumlah yang banyak, sedangkan gugud $\mathrm{NH}_{2}$ memiliki efektifitas sebagai antimikroorganisme dan mempengaruhi integritas pertumbuhan dari sel bakteri.

Konsentrasi kitosan 0,5\% menunjukkan KHM $71,27 \%$, kitosan $1 \% 82,28 \%$, sedangkan kitosan $2 \%$ menunjukkan KHM terbesar, yaitu $94,76 \%$. Hasil KHM membuktikan bahwa Candida albicans masih dapat hidup pada permukaan resin akrilik hingga konsentrasi kitosan $2 \%$. Jamur memiliki struktur yang lebih kompleks dibandingkan dengan bakteri, karena dinding jamur mengandung polisakarida dan kitin. Dengan demikian, untuk membunuhjamur diperlukan kandungan aktif yang lebih besar dibandingkan pada bakteri. ${ }^{18} \mathrm{Di}$ samping itu, jamur memiliki membran inti (prokariotik) yang menyelubungi inti DNA sehingga mampu memberikan perlindungan terhadap agen antimikroba yang lebih kuat dibandingkan dengan bakteri. ${ }^{19}$ Hasil penelitian ini membuktikan bahwa campuran resin akrilik dengan kitosan konsentrasi $0,5 \%, 1 \%$, dan $2 \%$ bersifat fungistatik sebab hasil $\mathrm{KHM}$ tertinggi pada konsentrasi $2 \%$ hanya mampu menghambat $94 \%$ atau kurang dari $99 \% .{ }^{20}$

\section{KESIMPULAN}

Campuran resin akrilik dengan kitosan konsentrasi $0,5 \%, 1 \%$ dan $2 \%$ menghambat pertumbuhan Candida albicans pada gigi tiruan dan bersifat fungistatik. Oleh karena itu, campuran ini dapat dikembangkan sebagai bahan gigi tiruan anti jamur. Penelitian ini perlu dilanjutkan dengan konsentrasi kitosan yang lebih tinggi untuk menghasilkan gigi tiruan resin akrilik yang bersifat fungisida.

\section{UCAPAN TERIMA KASIH}

Terima kasih kepada Kementerian Riset Teknologi dan Pendidikan Tinggi Republik Indonesia, atas dukungan beasiswa dan kesempatan untuk studi S3 di IImu Kedokteran Gigi, Universitas Gadjah Mada.

\section{DAFTAR PUSTAKA}

1. Riset Kesehatan dasar, Laporan Riset Kesehatan Dasar (Riskesdas), Badan penelitian dan pengembangan Kesehatan Kementerian Kesehatan Republik Indonesia; 2013. 110 - 118.

2. Powers JM, Sakaguchi RL. Craig's restorative dental materials, $12^{\text {th }}$ ed., Missouri: Mosby An Imprint of Elsevier; 2006. 58 - 59.

3. Schmalz G, Bindslev DA. Biocompatibility of dental materials. Springer-Berlin; 2009. $261-262$.

4. Harsini. Pengaruh ekstrak etanolik kulit batang jambu mete (Anacardium Occidentale Linn) sebagai bahan kumur terhadap daya perlekatan C.albicans pada plat resin akrilik. Majalah Kedokteran Gigi Indonesia. 2011; 18(2): 137 - 140.

5. Ramadhan LOAN, Radiman CL, Wahyuningrum D, Suendo V, Ahmad LO, Valiaveetill S. Deasetilasi kitin secara bertahap dan pengaruhnya terhadap derajad deasetilasi serta massa molekul kitosan. Jurnal Kimia Indonesia. 2010; 5(1): 17 - 21.

6. Kim IY, Seo SJ, Moon HS, Yoo MK, Park IY, Kim BC, Cho CS. Chitosan and its derivates for tissue engineering applications. Biotechnol adv. 2008; 26(1): 1 - 21.

7. Boynuegri D, Ozcan G, Senel S, Uc D, Uraz A, Ogus E, Cakilci B, Karaduman B. Clinical and radiographic evaluation of chitosan gel in periodontal intraosseus defect: a pilot study. $\mathrm{J}$ Biomed Mater Res B Appl Biomater. 2009; 90: $461-466$.

8. Li XF, Feng XQ, Yang S, Wang TP, Xingsu Z. Effects of molecular weight and concentration of chitosan on antifungal activity against aspergillus niger. Iranian Polymer Journal. 2008; 17(1): $843-852$. 
9. Kim JS, Shin DH. Inhibitory effect on Streptococcus Mutans and mechanical properties of the kitosan containing composite resin. Restor Dent Endod. 2013; 38(1): $36-42$.

10. Ismiyati $T$, Setyahadi $S$. Antifungal of thermoplastic nylon denture base plate incorporate with nanoparticle high density kitosan. J.Chitin - Chitosan Sci. 2014; 2(2): $1-7$.

11. Killay A. Kitosan sebagai antibakteri pada bahan pangan yang aman dan tidak berbahaya (review). FMIPA Universitas Pattimura; 2013. $200-201$

12. Tikhonov VE, Stepnova EA, Babak VG, Yamskov IA, Palma-Guerrero J, Jasson H, lopez-Lorca IV, Salinas J, Gerasimenko DV, Avdienko ID, Varlamov VP. Bactericidal and antifungal activities of a low molecular weight chitosan and its n-/2(3)-(Dodec-2-Enyl) Succinoyl/-derivatives. Carbohyd, Polym. 2006; 64: $66-72$.

13. Kurniasih M, Kartika D. Aktivitas antibakteri terhadap bakteri S.Aureus. Molekul. 2009; 4(1): $1-5$.
14. De Moura, Aouada FA, Mattoso LHC. Preparation of chitosan nanoparticles using methacrylic acid. J. Colloid Interface Sci. 2008; 321: 477 - 483.

15. Ravindra R, Krovvidi KR, Khan AA. Solubility parameter of chitin and chitosan. Carbohydrate Polymers. 1998; 36: 121 - 127.

16. Fraunhofer VJA. Dental materials at a Glance. USA: Wiley Blackwel; 2010. 178.

17. Pelczar MJ, Chan ECS. Dasar-dasar Mikrobiologi 2 (terj). UI Press, Jakarta; 2005. $43-45$.

18. Strand SP, Varum KM, Ostgaard K. Intractions between chitosan and bacterial suspensions: adsorption and flocculation. Colloids and Surface B Biointerface. 2003; 27: 71 - 81.

19. Hofkin. Living in a microbial world. New York: Garland Science; 2003. 330.

20. Madigan MT, Martinko JM, Parker J. Biology of Microorganism, $10^{\text {th }}$ ed. London: Pearson Education; 2003. $704-705$. 